\title{
Evaluation of Course Training Program on Research and Development Management of First Level Defense at Research and Development Agency Of Defense Ministry Republic of Indonesia
}

\author{
I Nyoman Astawa ${ }^{1}$, Muchlis R. Luddin ${ }^{2}$, Ma'ruf Akbar ${ }^{3}$ \\ ${ }^{1}$ Jakarta State University Postgraduate Program, \\ Rawamangun Muka Road, Jakarta 13220, Indonesia \\ ${ }^{2}$ Lecturer of IM MSDM on Jakarta State University Postgraduate Program as Promoter \\ Rawamangun Muka Road, Jakarta 13220, Indonesia \\ ${ }^{3}$ Lecturer of IM MSDM on Jakarta State University Postgraduate Program as Co-Promoter, \\ Rawamangun Muka Road, Jakarta 13220, Indonesia
}

\begin{abstract}
:
The research objectives are for analyzing, assessing, and improving the course training program on research and development management of first-level defense in terms of improving research resource competencies on Ministry of Defence. The research was using the Kirkpatrick evaluation model. Datum collection techniques were constructed with observation, interview, and documentation. Validation of research has been using data reduction, present and concludes. The research results illustrated that participants who following the training was highly reacted, strong motivated, and process of science transfer well conducted. However, the alumni of the training program on research and development management of first-level defense were not optimally empowered as researchers by the organization either in research and development of the Ministry of Defense or within the TNI. Thus, the out-of-training competency of the training as a researcher has not been empowered by the organization, so the research productivity of the alumni is very low. It is recommended that the Youth 'Litbanghan' Training and Training program can be used as a fundamental reference in formulating the functional position of the researcher who can serve as the career path for TNI soldiers.
\end{abstract}

Keywords: Evaluation, Training, Research and Development, Defense, Badiklat, Balitbang, TNI.

\section{Introduction}

The development of human resources within the Ministry of Defense is directed to support the main tool of modern weapon systems. In the Indonesian defense terminology, there were known national resources that include human resources, natural resources, and artificial resources. There are challenges in empowering defense researchers in addition to mastery of science and technology, as well as motivation and innovation in seeing the environment as a researcher. Empirical analysis (Ghisetti and Pontoni 2015) ${ }^{[1]}$ states the determinants of an analysis are technology, market share, strict policies, and the specificity factor of the company.

Building human resources as defense of a human capital, in line with the results of research (Alexe and Alexe 2017) ${ }^{[2]}$ which states the magnitude of the influence of innovation and human capital on the growth of industry and technology in Romania. It takes intellectual and social investment to foster innovation (Koroglu and Eceral 2015) ${ }^{[3]}$ and creativity in working to contribute both to teamwork (Morris et al 2014) ${ }^{[4]}$ and to organizational performance (Subramony et al., 2018) ${ }^{[5]}$. Efforts made to improve the ability of employees could be gotten through holding education and training by Training Agency of Defence Ministry (Badiklat Kemhan). According to (Piyali et al., 2012) ${ }^{[6]}$ predictions of effectiveness of training are determined by trainers and literature. While the basic steps to develop the training are job needs (Pederson, Dresdow and Benson 2013) $)^{[7]}$, this is consistent with the need analysis of the training that builds the relationship between the instructor and the objectives of the training and the collaboration (Harris et al 2014) ${ }^{[8]}$, as with the business world, 
entrepreneurship education can be undertaken at the University (Gámez Gutiérrez and Garzón Baquero 2017 ${ }^{[9]}$, but skills practice is carried out with a training program.

In line with Leonard S. Pederson, et al in 'Significant Tasks in Training of Job-Shop Supervisors' (Labadie et al., 2017) ${ }^{[10]}$ examines students of medicine, science, and innovation as programs that increase learning interest and understand their career goals in a level of trust high self. The research and development management of first level defense needs to be evaluated (Arasanz and Nylen 2017) ${ }^{[11]}$ so that the benefits from this program can really contribute to capacity building of relationships between researchers and organizations within the context of optimally empowering human resources in defense.

Evaluation as a science and also method, in this research uses the Kirkpatrick evaluation model which executed in February until April 2017 at Center for Education and Training of Defense Management Agency of Education and Training Ministry of Defense Pondok Labu Street on South Jakarta.

\section{Results}

\subsection{Stages of Reaction}

a. The curriculum of the program consists of basic study areas. Core studies areas, supporting study areas and other fields, with 481 lessons, conducted over three months. The division of a lesson based on the field of study is as follows.

\section{Curriculum Reaction}

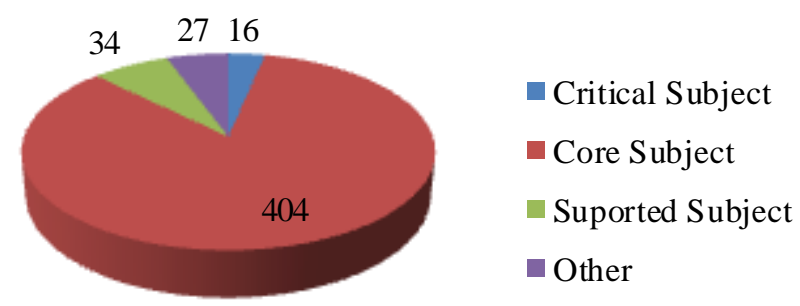

Figure 1.1 Chart of Lesson Sharing Lesson based on Field of Study taught on Training on research and development programs of first-level defense.

Increasing of lesson time for the subject matter of the core study is expected to master the scientific and technical field of research becomes increasingly dominant, so the materials taught are materials related to researching such as research management, research methodology, research design, data management, proposal and seminar research.

b. Widyaiswara is the assignment of functional and structural officials. Based on the assessment of the widyasiwara conducted by the training participants can be seen in the following table:

Table 1.1. Results of Participants' Assessment on Widyaiswara project

\begin{tabular}{|l|c|}
\hline \multicolumn{1}{|c|}{ Category } & Percentage \\
\hline Very satisfying & $1,85 \%$ \\
\hline satisfying & $41,48 \%$ \\
\hline good enough & $50,00 \%$ \\
\hline less satisfactory & $6,66 \%$ \\
\hline
\end{tabular}

Source: processed from the evaluation report of the Training on research and development programs of first-level defense of 2013, 2014 and 2015.

c. Teaching materials. Training materials prepared in the form of a written script. Based on the assessment of teaching materials used in the training can be seen in the following table:

Table 1.2. Results of Participants' Assessment on Teaching Materials Training on research and development programs of first-level defense

\begin{tabular}{|l|l|}
\hline \multicolumn{1}{|c|}{ Category } & \multicolumn{1}{c|}{ Percentage } \\
\hline Very satisfying & $1,66 \%$ \\
\hline Satisfying & $28,33 \%$ \\
\hline good enough & $61,66 \%$ \\
\hline less satisfactory & $8,33 \%$ \\
\hline
\end{tabular}

Source: processed from the evaluation report on the implementation of a training program on research and development management of first-level defense in 2013, 2014 and 2015.

d. The method used by widyaiswara / instructor in teaching and learning process is andragogy method. The technique of delivering the material through face to face in the form of lectures combined with discussion and question and answer. The following table shows the results from the assessment of training participants as follows:

Table 1.3. Results of Participants' Assessment of Teaching Methods used in the research and development training program of first-level defense.

\begin{tabular}{|l|l|}
\hline \multicolumn{1}{|c|}{ Category } & \multicolumn{1}{c|}{ Percentage } \\
\hline Very satisfying & $9,33 \%$ \\
\hline Satisfying & $46,67 \%$ \\
\hline good enough & $37,33 \%$ \\
\hline less satisfactory & $6,67 \%$ \\
\hline
\end{tabular}

e. Media The right and effective learning is one of the important factors in supporting the teaching 
and learning process. Based on the results of observation on the availability of existing learning facilities at the management center of the Ministry of Defense Training Agency can be seen in the following table:

Table. 1.4 Alins / Alongis used in Training on research and development programs of first-level defense.

\begin{tabular}{|c|c|c|c|c|c|}
\hline \multirow{2}{*}{ No } & \multirow{2}{*}{ Observation } & \multicolumn{5}{|c|}{ Scoring scale } \\
\hline & & $\mathbf{1}$ & $\mathbf{2}$ & $\mathbf{3}$ & $\mathbf{4}$ \\
\hline 1 & Whiteboard & & & & $\sqrt{ }$ \\
\hline 2 & Flip Chart & & & $\sqrt{ }$ & \\
\hline 3 & Overhead projector & & & $\sqrt{ }$ & \\
\hline 4 & Sound System & & $\sqrt{ }$ & & \\
\hline 5 & TV dan Video & & $\sqrt{ }$ & & \\
\hline 6 & LCD Projector & & & $\sqrt{ }$ & \\
\hline 7 & Computer & & $\sqrt{ }$ & & \\
\hline 8 & Wifi & $\sqrt{ }$ & & & \\
\hline
\end{tabular}

Note : $1=$ not good, $2=$ pretty good, $3=$ good, $4=$ very good

The participants' reaction to the existence of instructional media at the management center of the Ministry of Defense Training Agency is as follows.

Table 1.5. Results of Participants' Evaluation of Learning Media used training on research and development programs of first-level defense.

\begin{tabular}{|l|l|}
\hline \multicolumn{1}{|c|}{ Category } & \multicolumn{1}{c|}{ Percentage } \\
\hline Very satisfying & - \\
\hline Satisfying & $16,66 \%$ \\
\hline good enough & $66,66 \%$ \\
\hline less satisfactory & $16,66 \%$ \\
\hline
\end{tabular}

Source: processed from Head of Course and Inventory Room (DIR) data, as well as training participants' responses in 2017.

f. Training facilities are the supporting facilities and infrastructure needed in the education and training process. The available tools and infrastructure on the research and development programs of first-level defense in the management center of the Ministry of Defense Training Agency can be seen in the following table;

Table.1.6 Training Facilities available from the management center of the Ministry of Defense Training Agency

\begin{tabular}{|c|l|c|c|c|c|}
\hline \multirow{2}{*}{ No } & \multirow{2}{*}{ Observation } & \multicolumn{4}{|c|}{ Rate Scale } \\
\cline { 3 - 6 } & & $\mathbf{1}$ & $\mathbf{2}$ & $\mathbf{3}$ & $\mathbf{4}$ \\
\hline 1 & Class rooms & & & $\sqrt{ }$ & \\
\hline
\end{tabular}

\begin{tabular}{|c|l|c|c|c|c|}
\hline 2 & Discussion room & & & $\sqrt{ }$ & \\
\hline 3 & Computer Laboratory & & & $\sqrt{ }$ & \\
\hline 4 & Library & & $\sqrt{ }$ & & \\
\hline 5 & Mess & & $\sqrt{ }$ & & \\
\hline 6 & Food Store & & $\sqrt{ }$ & & \\
\hline 7 & Meeting room & & $\sqrt{ }$ & & \\
\hline 8 & Medical room & & $\sqrt{ }$ & & \\
\hline 9 & Praying room & & $\sqrt{ }$ & & \\
\hline 10 & Gym & & $\sqrt{ }$ & & \\
\hline 11 & Toilet & $\sqrt{ }$ & & & \\
\hline 12 & Store & & $\sqrt{ }$ & & \\
\hline 13 & Parking lot & & $\sqrt{ }$ & & \\
\hline Note : $1=$ not good, 2= pretty good, $3=$ good, $4=$ very \\
\hline
\end{tabular}

Participants' reactions to the Facilities at the management center of the Ministry of Defense Training Agency are as follows:

Table 1.7 Results of Participants' Assessment of Training Facilities available from the management center of the Ministry of Defense Training Agency

\begin{tabular}{|l|l|}
\hline \multicolumn{1}{|c|}{ Category } & \multicolumn{1}{c|}{ Percentage } \\
\hline Very satisfying & $5,12 \%$ \\
\hline satisfying & $28,46 \%$ \\
\hline good enough & $52,06 \%$ \\
\hline less satisfactory & $14,36 \%$ \\
\hline
\end{tabular}

g. The committee serves to provide all the needs of participants either from materials, facilities, teachers and other needs related to the implementation of the training. The organizing committee is an officer or an organic personnel from the personnel management center structure of the Ministry of Defense Training Agency. The participants' reaction to the organizing committee can be seen in the following table:

Table 1.8. Results of Participants' Assessment of the Organizing Training Organizing Committee available from the management center of the Ministry of Defense Training Agency

\begin{tabular}{|l|l|}
\hline \multicolumn{1}{|c|}{ Category } & \multicolumn{1}{c|}{ Percentage } \\
\hline Very satisfying & $6,43 \%$ \\
\hline satisfying & $38,46 \%$ \\
\hline good enough & $42,06 \%$ \\
\hline less satisfactory & $4,05 \%$ \\
\hline
\end{tabular}

Based on the participants' reaction to the $42.06 \%$ training organizing committee stated that they are satisfied, it shows that the service on the committee is good in the implementation of the training.

\subsection{Learning Stages}


The aspect that is evaluated in this level is the motivation to learn and increase the competence of training participants.

a. The motivation to learn the training participant is very different. The results of observation shows the activity of participants during the learning process is always colored by asking for something that is not understood. This happens because the source / origin of the training participants not all come from scholars who have known the theory and methods of previous research.

b. Increased competence based on the results from the evaluation of learning shows an increase, it can be seen in the following table:

Table 1.9. Assessed Test Results of Participants before and after following used training on research and development programs of first-level defense.

\begin{tabular}{|l|c|c|c|c|}
\hline \multirow{2}{*}{} & \multicolumn{2}{|c|}{2015} & \multicolumn{2}{c|}{2016} \\
\cline { 2 - 5 } & $\begin{array}{c}\text { Pre } \\
\text { Test }\end{array}$ & $\begin{array}{c}\text { Post } \\
\text { Test }\end{array}$ & $\begin{array}{c}\text { Pre } \\
\text { Test }\end{array}$ & $\begin{array}{c}\text { Post } \\
\text { Test }\end{array}$ \\
\hline $\begin{array}{l}\text { The highest } \\
\text { score }\end{array}$ & 64,44 & 65,00 & 60.00 & 80.00 \\
\hline $\begin{array}{l}\text { The lowest } \\
\text { score }\end{array}$ & 31,11 & 31,11 & 30.00 & 37.50 \\
\hline average & 49,33 & 49,77 & 47.00 & 50.43 \\
\hline
\end{tabular}

Source: An evaluation report on education and training on research and development programs of first-level defense

The results from the assessment of the presentation include academic, personality and physical values of training participants who can be seen in the following table:

Table 1.10. Result of Assessment Achievement learners training on research and development programs of first-level defense

\begin{tabular}{|l|l|l|l|l|}
\hline Result & $\mathbf{2 0 1 3}$ & $\mathbf{2 0 1 4}$ & $\mathbf{2 0 1 5}$ & $\mathbf{2 0 1 6}$ \\
\hline The highest score & 84,02 & 86,39 & 86,20 & 87,23 \\
\hline The lowest score & 78,32 & 81,06 & 81,45 & 80,07 \\
\hline average & 81,94 & 83,23 & 83,71 & 83,65 \\
\hline
\end{tabular}

Source: Implementation evaluation report of the training of 2013-2016

Based on the findings above shows that there is an increase in competency capacity of training participants. Post test results have increased compared to before the training, then the results from the assessment of student achievement based on academic and physical values above 80. This result means that the implementation of training programs on research and development management of first-level defenses very good based on test scores and able to improve the competence of training participants.

\subsection{Behavior Stages}

At this stage of evaluation, Behavior is assessed is the change from the behavior of training participants, including the alumni after they returned to working in their respective organizational units. Based on the observed data of alumni observation, there is a change of knowledge and skill aspect. However, the science obtained cannot be applied to the work environment, because the task and function, there is no relevance to the outcome of training. The last data shows the year 2016 of the participants 30 people only two people $(6.67 \%)$ derived from institutions of Research and Development while the remaining 28 people $(93.33 \%)$ came from non-Research and Development institutions. From the above data, change from the behavior of alumni is very difficult to measure because the knowledge and skills acquired after attending the training are faced with their tasks, and work functions are very different.

\subsection{Stages of Results}

The findings in the field, alumni who work or served in the environment $\mathrm{R} \& \mathrm{D}$ are very a lack of this can be seen through the picture below:

\section{Alumni Empowerment}

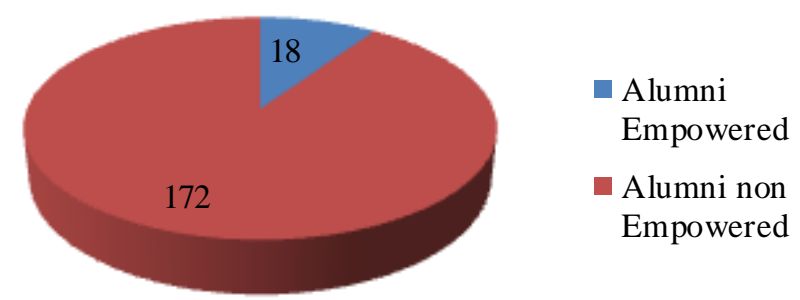

Figure 1.2 Graph Presentage Number of Year 2013-1016 Alumni Empowered at Research and Development Institution in Ministry of Defense and TNI

\section{TNI AL (NAVY) R n D Personnel}

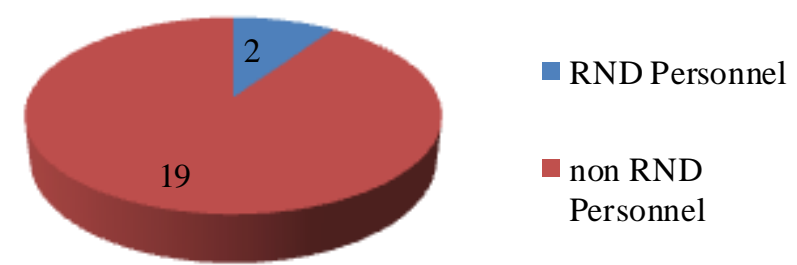

Figure 1.3. Graph of Percentage of research and development personnel of NAVY having qualified training on research and development programs of first-level defense 


\section{TNI AD (Army) R n D Personnel}

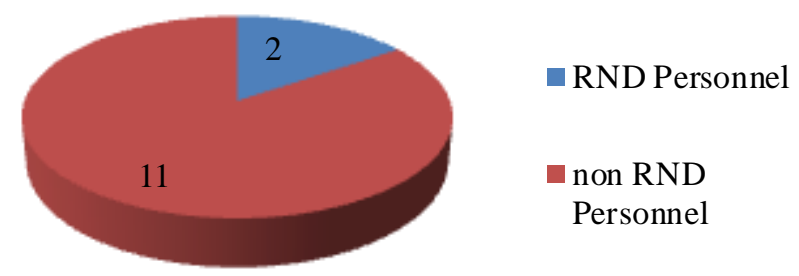

Figure 1.4. Graph of Percentage of research and development personnel of Army having qualified training on research and development programs of first-level defense

From the picture above shows that the R \& D human resources which have educational qualifications training on research and development programs of first-level defense under $20 \%$, can also mean that effort to increase the capacity of human resources researchers who come from $\mathrm{R} \& \mathrm{D}$ institutions is very lacking. There are 190 alumni training programs on research and development management of first-level defense during the 2013-2016 timeframe. From the data, which is assigned in the Research and Development Agency only 18 people and even then not entirely become researchers. The remaining 172 alumni are scattered in various entities with duties and functions outside of the study, so that the training alumni have not been optimally empowered by the organization and its leadership, resulting in the productivity of the research results is absent or very low.

\section{Discussion}

As the theoretical reference and research results presented earlier, the results of field observations and studies of the results of interviews in the following discussion as follows:

\subsection{Stages of Reaction}

Training on research and development programs of first-level defense is a Brain Power investment program that is an intellectual capital. TNI soldier who becomes training participants is an investment. The learning process is well prepared, ranging from a curriculum developed and implemented based on goal-oriented principles, educational relevance, efficiency, effectiveness, flexibility and sustainability, teaching materials, learning materials, learning methods, learning media, facilities, committees, and other supporting instruments. It is based on need's analysis (Allal-Chérif and Bidan $2017)^{[12]}$ as the internal and external influences of a five-dimensional culture, knowledge, innovation, and desires. Against the readiness, all participants in the training gave a very positive reaction.

\subsection{Learning Stages}

A person is said to have learned if there is a change in behavior that is permanent or fixed behavior. Field observation data stated that all alumni had mastered the knowledge about R \& D obtained from teaching-learning process in Ministry of Defense $\mathrm{R}$ \& D. Implementation of the training is seen from the effectiveness of the implementation of training programs that develop job need analysis (Pederson et al., 2013) still not directed.

The results of field objectivities and document studies show the motivation of high education participants with the dynamic of a strict learning process. Similarly with the results from the training, the data show the increased ability of participants either in mastery of science with the methodology, as well as innovation and critical thinking.

\subsection{Behavior Stages}

In the report on R \& D of Ministry of Defense, R \& $\mathrm{D}$ TNI AD, and R \& D TNI AL, there are research activities in the form of studies involving personnel structurally. After being scrutinized, the team formed was supervised by the Head of the Human Resources sub directorate, where no one personnel from the alumni training program on research and development management of first-level defense were involved in the team. This means that all of them are structural officials who are the research team.

That this program can make changes to the role of training participants by improving the ability of ordinary employees to be educated and developed into professional researchers. Supported by coach factors and relationships with participants (Piyali et al. 2012) being the most effective variables in the training. This is not done comprehensively, so TNI personnel who have attended training on research and development management of first-level defense have not been empowered in the research work, and their competence cannot be utilized for organizations in conducting synergistic research and team.

This contrasts with the building of competence and high motivation (Labadie et al., 2017) shown by the training participants in following the whole set of 
materials. All the newness values obtained during the training, ended and cannot be applied for the assignment, because the work orientation is different. Similarly (Allal-Chérif and Midwife 2017) programs developed at significant cost free of charge to training participants have no effect on organizational culture of $\mathrm{R} \& \mathrm{D}$ and uninvolved working relationships. Innovation of instructors (Harris 2014) and (Harris et al 2014) who prepare all their resources and efforts to find a training catalyst, so that the Training Board as an organizer and R \& $\mathrm{D}$ agency as a sending organization do not become socially disadvantaged, because human capital is not achieved. R \& D performance is influenced by the interaction between actors in innovation (Chen and Hung 2016) ${ }^{[13]}$ mainly technology innovation strategy into Indonesia's defense industry policy does not overshadow training out. So that the training outputs are not able to answer the R \& D objectives undertaken by the company, and analyze the financial impact, knowledge, and market barriers to $\mathrm{R} \& \mathrm{D}$ innovation as the reference is used (CostaCampi, Duch-Brown and García-Quevedo 2014) ${ }^{[14]}$.

\subsection{Stages of Result}

Starting from examining organizational performance models with human capital and social capital as mediators, (Subramony et al., 2018) is primarily for building the knowledge, skills, and intrapersonal skills of leaders. The realization of quality research, full of innovation and challenging future strengths into an organizational performance assessment determined by the influence of leaders in running strict rules / policies, this will be correlated with $\mathrm{R}$ \& D (Ghisetti and Pontoni 2015) as an organization.

Fundamentally, the analysis of training needs to increase knowledge, skills, and competence as a researcher does not contribute to the performance within the organization. Judging from the contribution of alumni works as a team in conducting research in R \& D agency is very low, it can be interpreted the implementation of training need to be evaluated fundamentally. An alternative to be able to accommodate the competence of alumni of training to be empowered is the commitment of leadership in the effort to maximize the training competence, and the opening of functional position of researcher for TNI soldier as career path.

\section{Conclusions}

- Participants' reactions to the training of research programs on research and development management of first-level defense showed satisfactory reaction both from the curriculum, teaching materials, teaching staff, learning methods used and the learning media, committees, and facilities available.

- Achievement of learning outcomes that have increased by comparing the results of pre-test and post test; then the acquisition of average achievement score of participants by $80 \%$, so that the training participants can be declared passed and have increased competence. High motivation has encouraged each participant able to prepare a research proposal, mastering methodology, able to formulate / make research instrument, able to process data, and competent to make a report of research results.

- The evaluation results on the behavior stage, which shows that the alumni are not maximal in applying the skills, and knowledge gained from the training. This is caused by the source of the training participants are mostly not from the research institution so that after the training the participants return to the unity of origin that is not in accordance with the competence of the researcher.

- The result from the evaluation shows that the training on research and development program of first-level defense does not give a significant impact to the organization, especially the existing $\mathrm{R}$ \& D institutions, both within Kemhan and R \& $\mathrm{D}$ within the TNI. This is because some alumni are not enabled or not empowered because they are not assigned to $\mathrm{R} \& \mathrm{D}$ institutions. The alumni do not conduct research that can be used by the organization because they do not carry out research work according to their competence, so there is no research work produced as an institution product.

- Equalize the length of your columns on the last page. If you are using Word, proceed as follows: Insert/Break/Continuous.

\section{References}

[1] Ghisetti, C. \& F. Pontoni (2015) Investigating policy and R\&D effects on environmental innovation: A meta-analysis. Ecological Economics, 118, 57-66.

[2] Alexe, C.-M. \& C.-G. Alexe (2017) Human Capital Practices Drive Innovation in Romania. Procedia Engineering, 181, 943-950. 
[3] Koroglu, B. A. \& T. O. Eceral (2015) Human Capital and Innovation Capacity of Firms in Defense and Aviation Industry in Ankara. Procedia - Social and Behavioral Sciences, 195, 1583-1592.

[4] Morris, M. W., K. Savani, S. Mor \& J. Cho (2014) When in Rome: Intercultural learning and implications for training. Research in Organizational Behavior, 34, 189-215.

[5] Subramony, M., J. Segers, C. Chadwick \& A. Shyamsunder (2018) Leadership development practice bundles and organizational performance: The mediating role of human capital and social capital. Journal of Business Research, 83, 120-129.

[6] Piyali, G., S. Rachita, J. Jagdamba Prasad, R. Rashmi \& S. Priya (2012) Towards more effective training programmes: a study of trainer attributes. Industrial and Commercial Training, 44, 194-202.

[7] Pederson, L. S., S. Dresdow \& J. Benson (2013) Significant tasks in training of job-shop supervisors. Journal of Workplace Learning, 25, 23-36.

[8] Harris, T. B., C. Wonjoon, M. H. Holly \& S. C. Dan (2014) Do trainer style and learner orientation predict training outcomes? Journal of Workplace Learning, 26, 331-344.

[9] Gámez Gutiérrez, J. \& J. E. Garzón Baquero (2017) New cross-proposal entrepreneurship and innovation in educational programs in third level (tertiary) education. Contaduría y Administración, 62, 239-261.

[10] Labadie, B., R. M. Patel, J. Gandy Labadie, C. Hwang, Z. Okhunov \& J. Landman (2017) Assessing the Effect of an Intensive 2-Week Surgical Training and Innovation Program for High-School Students. J Surg Educ, 74, 958967.

[11] Arasanz, C. \& K. Nylen (2017) The theory of change of the evaluation support program:
Enhancing the role of community organizations in providing an ecology of care for neurological disorders. Eval Program Plann.

[12] Allal-Chérif, O. \& M. Bidan (2017) Collaborative open training with serious games: Relations, culture, knowledge, innovation, and desire. Journal of Innovation \& Knowledge, 2, 31-38.

[13] Chen, P.-C. \& S.-W. Hung (2016) An actornetwork perspective on evaluating the $R \& D$ linking efficiency of innovation ecosystems. Technological Forecasting and Social Change, 112, 303-312.

[14] Costa-Campi, M. T., N. Duch-Brown \& J. García-Quevedo (2014) R\&D drivers and obstacles to innovation in the energy industry. Energy Economics, 46, 20-30.

[15] Gosim Martin, C. (2016) Trainer attributes as drivers of training effectiveness. Industrial and Commercial Training, 48, 367-373.

[16] Angela Baron dan Michael Armstrong, Human Capital Management terjemahan Lilian Juwono (Jakarta: PPM, 2013)

[17] Arikunto. Suharsimi dan Cepi Safruddin Abdul Jabar. Evaluasi Program Pendidikan. Jakarta: Bumi Aksara, 2014.

[18] Donni Juni Priansa, Perencanaan dan Pengembangan SDM. (Bandung: Alfabetha, 2014)

[19] Kasmir, Manajemen Sumberdaya Manusia (Teori dan Praktik) (Jakarta: Rajawali Press, 2015)

[20] Raymond A. Noe, Employee Training and Development (New York: McGraw-Hill, 2013).

[21] Tjutju Yuniarsih dan Suwatno, Manajemen Sumberdaya Manusia (Bandung: Alpabetha, 2013) 